\title{
Origin and evolution of tomato production Lycopersicon esculentum in México
}

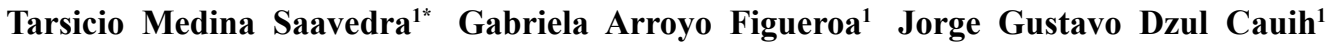

${ }^{1}$ Departamento de Ingeniería Agroindustrial, Universidad de Guanajuato, Campus Celaya Salvatierra, Privada de Arteaga, s/n, 38900, Salvatierra, Gto. E-mail: tarsicioms@hotmail.com. "Corresponding author.

\begin{abstract}
Lycopersicon esculentum known as tomato, although has an Andean origin is a contribution of Mexico to the world is, being the first agricultural product to be exported. This research aimed to review the literature in relation to the origin and evolution of the production of tomato in Mexico within the historical development of the country. In ancient times, the tomato was cultivated in milpas (open field) and chinampas (artificial islands for riparian agriculture) using sustainable methods. Spanish colonizers showed the tomato to the rest of the world and diversified its uses. In independent Mexico, haciendas and railroads integrated the different farming regions. Production decreased during the Mexican revolution, and with land reform, the milpa returned. During the Green Revolution (1970), Sinaloa stood out, with the separation of two systems, subsistence, and modern with technology programs. Biotechnological development (1990) emerged parallel to organic production. So actually with this system, we could return to more sustainable pre-Hispanic ecological principles with less environmental impact.

Key words: Lycopersicon esculentum, chinampas, green revolution, organic production, biotechnology.
\end{abstract}

Origem e evolução da produção de tomate Lycopersicon esculentum no México

RESUMO: Lycopersicon esculentum conhecido como tomate, uma contribuição do México para o mundo a partir de sua domesticação, embora sua origem seja andina, é o primeiro produto de exportação agrícola. Esta pesquisa tem como objetivo realizar uma revisão da literatura em relação à origem e evolução da produção de tomate no México e, no desenvolvimento histórico do país. Nos tempos antigos, o tomate foi cultivado em milpas (campo aberto) e chinampas (ilhas artificiais para a agricultura ribeirinha), utilizando métodos sustentáveis. Colonizadores espanhóis introduziram o tomate no restante do mundo, diversificando seus usos. No México independente, fazendas e estradas de ferro integram as diferentes regiões agrícolas. A produção diminuiu durante a revolução mexicana, e com a reforma agrária ocorreu o retorno da milpa. Sinaloa destacou-se durante a Revolução Verde (1970), com a separação dos dois sistemas de subsistência e moderno e, com programas de tecnologia. O desenvolvimento biotecnológico (1990) surge em paralelo à produção biológica. Dada a complexidade do panorama dos alimentos, atualmente, com estes sistemas, podem-se retomar os princípios ecológicos pré-hispânicos mais sustentáveis, com menor impacto ambiental.

Palavras-chave: Lycopersicon esculentum, chinampas, revolução verde, produção biológica, biotecnologia.

\section{INTRODUCTION}

The spanish found in the American hemisphere a herbacea plant whose fruit was edible, called "tomatl", which translated to Spanish became tomato (PORCUNA et al., 2012). In the center of Mexico this plant is known as "xitomate" from the Nahuatl language, "xictli to the navel and" tomatl "for tomatoes or tomato navel., which means navel tomato (SAGARPA, 2010) to differentiate it from the tomato or tomatillo green, that has a shell (Physalis ixocarpa L.) both belonging to Solanáceas family (SÁNCHEZ, 2003). The mexicans in its heyday (centuries XIV to XVI) cultivated tomato in a polyculture system called milpa and due to the conditions of the soils, characterized by abundant swamps and wetlands the chinampas were developed and constituted a element of local identity (GONZÁLEZ \& TORRES, 2014).

The tomato (Lycopersicon esculentum), red tomatoes or tomato plant is the most widespread contribution of Mexico throughout the world, with a great variety of culinary uses. The inclusion of tomato in the gastronomy is only comparable to the one made by the frenchman Antoine Parmentier with potatoes in the eighteenth century (CLÉMENT, 1995).

Although the tomato is known in Europe in the sixteenth century, its widespread consumption occurred two hundred years later due to the distrust of consumers and botanists, 
since it was considered only an ornamental plant of the mandrake family (VERGANI, 2002). A small perennial plant of the Mediterranean area, capable of killing those who consume alkaloids (GÓMEZ, 2011); although, the tomato was already consumed in Italy, seasoned with oil, salt and pepper (VERGANI, 2002).

The twentieth century, with the green revolution resulted on improvement and marketing of F1 hybrids, determining the development of crops coupled with the momentum of the great irrigation works. The collection, description, propagation, and distribution of genetic materials of Dr. Rick Charlie who organized numerous expeditions to the Andes to the hunting of wild species of tomato, were the key to the development of new varieties (BAI \& LINDHOUT, 2007). In 2005, two new species of wild tomatoes were identified in regions of Peru (PERALTA et al., 2005); however, at the beginning of the nineties, the development of varieties of indeterminate growth or long-life improved quality factors as firmness, color, flavor and conservation.

Mexico celebrates annually the "the Tomato day", which is considered a crop of great social and economic value. According to the AgriFood Information System and fishing (SIAP) of the Secretariat of Agriculture, Livestock, Rural Development, Fishing and Food (SAGARPA) tomato cultivation generates 72 thousand direct jobs and approximately 10.7 million indirect jobs. The area sown in 2009 was of 101 thousand 328 hectares, reaching yields of 39.5 tons per hectare (SAGARPA 2013). According to data from the same SAGARPA (2015), Mexico is the leading exporter of tomatoes in the world with 2.8 million tons in 2014.

Through a review of literature, the present research seeks to understand the origin and evolution of the tomato production in Mexico within its historical development, from the pre-hispanic era with their farming systems as milpa and chinampas, through the colonial and independence period with new instruments of tillage and monocultures, ending currently with the use of biotechnology, applied to conventional agriculture and to ecology.

\section{Tomato in ancient times}

The origin of the tomato is in the Andean region of Colombia, Chile, Peru, and Bolivia (PERALTA \& SPOONER, 2007; SIMS, 1980). However, there are indications that domestication occurred in Mexico (BAI \& LINDHOUT, 2007), some people mentioned Puebla and Veracruz as specific placesdue to the largest number of varieties; although, the variety used in preHispanic cooking was the green tomato or husk tomato (LONG, 2013).

At the time of the old Tenochtitlan, the capital of the Anáhuac, and the colonial city of palaces, had the technological and cultural elements of a highly developed lake-side civilization (EZCURRA, 1990; RUBIO, 2007). The city was located more than 2,200 meters above sea level on an island in the western part of Lake Texcoco. The city was repleted with dirt roads, water channels, and several roads which connected the island to the land. Here, farmers built artificial islands and floating gardens (DE LA ROSA, 1986; RUBIO, 2007).

The agricultural system was Aztec and they used chinampas, or shallow beds in a lacustrine zone. Cultivation in chinampas is a highly productive intensive agriculture where nutrients are recycled very efficiently by transportation to the bottom of the lake by rain on the farmland, and the subsequent harvest of aquatic plants in the water channels (FAO, 2007; EZCURRA, 1990). Crops were harvested to feed the population using this system, considering that there may have been from 60,000 to $1,000,000$ or more million people, which is contested by historians, but surely the population was one of the largest of its time (LÓPEZ, 1990; DE LA ROSA, 1986).

Mexicans were the first to build chinampas in the thirteenth century, to increase the arable land in the Mexico valley (GONZÁLEZ \& TORRES, 2014). Most plants grown in chinampas are first planted as seedlings. Red tomato was cultivated in the dry season due to its sensitivity to moisture and at the end of the harvest. The same area was used for planting husk tomato in partnership with chili to reduce pests and crop rotation with pulses (LONG, 2013).

Milpa, which means "what is sown on the plot" (CABRERA, 1980) is an agroecological production system used from prehistoric times until today to grow corn in association with beans and pumpkin (AGUILAR et al., 2003). The milpa is a space where food is cultivated in biological and economic harmony and not a monoculture of corn interspersed with other crops. Corn was the basis of the pre-hispanic diet along with pumpkin, tomatoes, beans, and other edibles like quelites (a general term referring to common plants such as amaranth or other plants now considered 
weeds), huauzontle, purslane, and medicinal and fodder plants, taking advantage of the interaction between species such as beans that fix nitrogen that subsequently helps the corn to grow (ASTURIAS, 2004; VELA, 2013).

The cornfield technology over time has required adaption to various aspects such as agricultural calendars, other cultural practices, and ways of preparing and using seeds, fertilizers, farm tools, and various techniques that are considered ecologically correct (ZAVALA, 1998; EK, 2012).

\section{The tomato in colonial times}

During Spanish colonization, the tomato was used in Mestizo and European meals. However, it was not part of the staple diet of indigenous people, and it was considered as ground cover over the cornfields (LONG, 2013). After the conquest, the cities of the basin were redesigned according tosspanish plans. Wetlands mismatched the new style of construction and land use, so drainage were created to dry the muddy soil. The drainage caused gradual changes to the environment of the basin, starting with the loss of agricultural chinampas and environmental deterioration (BUENO, 2007; EZCURRA, 1990).

With the merger of the colonial and native culture, important changes occurred in production. Corn was the staple crop, along with beans, squash, amaranth (Amaranthus and Quenopodium) cultivated as well as wild, chili, tomato cultivated and wild (tomatillo), maguey (which also provided honey and worms), nopal and native fruits such as wild cherry (Prunus), hawthorn (Crataegus) and white sapote (Casimiroa edulis). Spaniards added wheat, fava beans, various vegetables and fruit trees, and over time sugar cane displaced maguey honey, and vegetables took amaranth place (GONZÁLEZ, 2001), with new farming methods, irrigation systems were destroyed, soils were overexploited and diseases proliferated (Aguilar et al., 2003; CRAMAUSSEL \& CARBAJAL, 2010).

The coa, a specialized hoe, used as a tool for indigenous farmland was replaced in the late sixteenth century by the plow, and the work related to it was integrated intoNahua farming activities allowingclay bottom cultivation, hithering untouched coa (AGUILAR et al., 2003; BUENO, 2006). Indigenous people used a polyculture system with minimum tillage which included tomatoes, and the Europeans tilled the soil with their plows helped by draft animals and broadcast large areas of a single crop harvested with scythes (CRUZ et al., 2010).

With the loss of much of the population due to a series of terrible epidemic disasters during the $16^{\text {th }}$ century, many intensive systems such as raised fields and terraces, especially in the humid forests were abandoned, and the vegetation was regenerated in areas that had been agricultural (AGUILAR et al., 2003, JOHANSSON, 2012). There are indications in recipes and paintings that the tomato was already being used in the Spanish cuisine since the mid-seventeenth century, adopting Aztec methods such as sauces, with Italy and Spain becoming the first countries where it was grown outside Americas (LONG, 2013).

\section{The tomato in independent Mexico}

In the early eighteenth century, in the Haciendas and ranches, it was common to use animals for different agricultural practices using mules as pack animals and oxen as draft animals for agricultural tools as plow. Rural properties that were considered as large estates were church properties and communal properties of indigenous peoples (CRUZ et al., 2010). During reform laws, ordinances confiscation and nationalization of church properies not giving land was given to peasants, so they were like pawns on large estates (GARFIAS, 1981; OLIMÓN, 2009).

At Porfirio's presidency, huge estates were established, and exports were promoted, among which was the tomato. With the development of communications, railways and roads led to the gradual integration of remote regions to national and international markets (AGUILAR et al., 2003; ZULETA, 2000). During this period agriculture was represented by the estate as a production unit, with an economy based on the export of natural resources, cheap labor and foreign capital and technologies, especially in the industrial sector economy. Agriculture support $70 \%$ of the population by progress in commercial agriculture and subsistence production where the majority is compounded by the growth rate works (MEYER 1986; ZULETA, 2000).

Most of the irrigation of Porfirio Diaz government were created by large landowners and foreign companies that took advantage of the irrigation canals to grow tomatoes and vegetables (ZULETA, 2000). In Sinaloa 63 irrigation canals were built to produce food for the US market, after the dispossession of indigenous owners by legal means and procedures as the denunciation of seemingly 
owners, protected by the registration law issued by Diaz (LÓPEZ 2013). With the 1910 revolution and the agrarian reform, which mainly occurred in the thirties, half the arable land was put in the hands of peasants, which generally returned to milpas (AGUILAR et al., 2003; ZÚÑIGA \& CASTILLO, 2010). During the revolution, there was a drastic decline in tomato production which was reversed after 1917. Then began a gradual rise that accelerated after 1925 , reaching a maximum (100 thousand tons) between 1927 and 1929 (CARRILLO, 2004).

The few data reported during the period 1910-1920 reflected agriculture in two different perspectives: e conversely, crops for export or to maintain their level increases, including cotton, sugar cane and henequen; for domestic market oriented crops production, which was affected between 30 and 50\% (SCHETTINO, 2007).

To land reform of President Lazaro Cardenas (1934-1940) ejidatarios farmers from deprived post-revolutionary origin emerged and rancher as social and economic group disappeared, highlighting the state of Sonora in the production and export of tomatoes. However, an atmosphere of distrusted investments was created in the country, specifically in the ejidal sector, which caused a drop in production of $43 \%$ (ROMÁN, 2013).

\section{The tomato and the green revolution}

During the 1941-1976 period, production far exceeds 100,000 tons, increasing to a maximum of 1,200 tons in 1972 , highlighting Sinaloa with $50 \%$ of the national production, and finally back to decrease of production to 806,000 tons in 1976 (CARRILLO, 2004). These increases in production are given not only by the increase in cultivated acreage but also by programs of irrigation with the construction of dams and change in production system technology used since the late fifties, especially the passage of tomato cultivation from the floor to the cane (CERUTTI \& LORENZANA, 2008; SOTO, 2003).

Since 1977, there has been a rapid growth in tomato production. In 1978, it exceeded one million tons, and ten years later, it exceeded two million for four consecutive years (1988-1991). Post-2000 production remains just over two million tons; lower than the last years of the nineties. These increases no longer corresponded to the cultivated area as it increased from 600 thousand to 800 thousand hectares in 1977-1990 related more to the technology used (CARRILLO, 2004).

Importantly, there are two farming systems that are beginning to be separated, traditional agriculture based on the spontaneous empirical knowledge of low-income farmers, of predominantly subsistence production and a culture accumulated by generations (REMMERS, 1993; SOTO, 2003), and conversely, modern agriculture that use nitrogen, improved varieties and agrochemicals to increased production Decades ago, crop yields in agricultural systems depended on internal resources, recycling of organic matter, biological control mechanisms and rainfall patterns, yields were modest but stable and secure, with more than one crop (ALTIERI, 1999; GONZÁLEZ, 2004).

During the period 1960-1990, when there was a boom in agricultural productivity in the developing world called green revolution, especially in Asia and Latin America, modern science was used to find ways to produce more food, which revolutionized agricultural activity (GARCÍA, 2005). La desigualdad en las zonas rurales, aumento de la dependencia tecnologica, erosión de la base genética, $\mathrm{y}$ aumento de plagas y enfermedades. (ALTIERI, 1999; GONZÁLEZ, 2003).

Progress has been made on the type of tomato plant, there are two distinct types: determinate and indeterminate. The determinate is a bush, short-statured, small and with early production, characterized by the formation of inflorescences in the extreme apex. Indeterminate tomato grows to heights of 2 meters or more, depending on the side or tutoring used, being the vegetative growth continuous (HERNÁNDEZ, 2003).

The physiological processes of growth and development of tomato plants depend on weather conditions, soil and genetic characteristics of the variety (HAEFF, 1983; ORTEGA et al., 2010). A wide variety of tomatoes are cultivated in Mexico, which for practical purposes can be classified, according to SAGARPA, as cherry tomatoes, organic cherry tomato, red organic tomato; red tomato (export); red tomato (industrial); red tomato (fresh), red greenhouse tomatoes, saladette red tomato and saladette red tomato for seed (HERNÁNDEZ, 2003).

Actually, the open field tomato crop is becoming ever more difficult to cultivate due to adverse environmental conditions such as temperature(frost), cloudiness (cloud), precipitation (rain, hail, dew, snow, and frost) and the incidence of pests and diseases (MONDRAGÓN, 2007; BERRUETA et al., 2012; JUÁREZ et al., 2012). Differences could be noted because there was the need for greenhouses to achieve high levels of quality, food safety, product certification to reach 
the final customer (PACHECO, 2008), in difficult times to produce in open field from July to August and November to December (Mondragon, 2007).

The North American Free Trade Agreement (NAFTA) provides the production, consumption, and trade of tomatoes between the three countries; however statistics indicated that after the elimination of tariffs in 1994, Mexican tomato exports to US markets only increased by 4.7 thousand metric tons, indicating that Mexican exports are based on factors beyond tariff barriers (GARCÍA et al., 2005).

Tomato production in greenhouses has attracted attention in recent years, based on the perception that greenhouse tomatoes can be more profitable than agronomic crops or horticultural crops in the open field (SNYDER, 2006; BOJACÁ et al., 2009).

Alternatively, hydroponics, focussed on preventing leachate, thereby preventing the contamination of soils and groundwater by collecting water for reuse, keeping the root system of the vegetable confined in a container, ensuring an optimum air-water ratio in the root system,. In this way nutrition is much more controlled, and inert substrates are found free of pests and diseases (GILSANZ, 2007).

\section{The tomato and biotechnology revolution}

After the time called green revolution, with its effects on the environment and social organization, emerges the new green revolution, related to modern biotechnology (Barrera, 2011). The main genetically modified crops are corn, soybeans, rapeseed, tomato, melon, beets and potatoes, whose genetic modification focuses on resistance to herbicides and insecticides (SEGRELLES, 2005).

On May $18^{\text {th }} 1994$, the American Food and Drug Administration (FDA) approved the sale of the Flavr-Savr (or 'MacGregor') tomato, changing its appearance, flavor and above all, maturity time to and conservation (longer shelf life) (RODRÍGUEZ, 2003). With genetically modified organisms (GMOs) come the patented products and the big biotech groups that deprive farmers of free access to seeds (SEGRELLES, 2005).

In response to the green and biotechnology revolution, neoliberal globalization processes, trade liberalization, sacralization of the market and productivism, expansion of agro-genetics and privatization of living matter and nature, organic or sustainable agriculture is presented as an alternative, based on the cultivation without agrochemicals and recovering biodiversity as the only way to survive to total human, rural, agricultural, cultural, biological and ecological disaster (ALTIERI, 1999; TOLEDO, 2002; SEGRELLES, 2005).

A large market opportunity arise for mexican producers of tomatoes specially for tomatoes that are organically produced, which has a very broad market, mainly in the European Union (HERNÁNDEZ, 2003), who untill today has been restrictive in the use of genetically modified organisms (RODRÍGUEZ et al., 2003).

There are key moments in the evolution of the tomato production from its domestication by pre-hispanic cultures to sustainable systems, diversification of uses to make it known worldwide and currently increase in productivity due to technological advances in seed and agrochemicals, as well as the search for systems with lower environmental impact (Table 1).

\section{CONCLUSION}

Although the tomato is of Andean origin, domestication occurred in Mexico through biodiverse systems of production and utilization of large wetlands through the chinampas, a method of intensive and highly productive agriculture. At the time of colonization, agricultural systems were redesigned according to new lifestyles, resulting in the fusion of colonial and native culture, replacing the coa by plowing and minimum tillage by monoculture, and the Aztecs methods of the use of tomato sauces were adopted in Europe.

The forms of land ownership and the haciendas, developed at the time of independent Mexico, especially in the presidency of Porfirio Diaz, caused positive impact on the production and export of tomato, with the development of irrigation and the integration of regions using the railway.

As At the 40s, the production of tomato exportation increased significantly due to the momentum of large hydraulic use of improved seed varieties and use nitrogen fertilizers and agrochemicals. The entry into force in 1994 of the Free Trade Agreement (NAFTA) with the United States and Canada had a positive effect on tomato production; however, other factors with greatest impact are considered, such as the use of varieties of indeterminate growth, promoting greenhouse production and development of biotechnology. Conversely, organic tomato production is a response to the environmental impacts of conventional production 
Table 1 - Important moments in the tomato evolution.

\begin{tabular}{l|l}
\hline Time & Origin: Colombia. Peru, Bolivia, Chile \\
\hline Pre-Hispanic & Domesticated in Mexico (Veracruz and Puebla) \\
\hline & Sustainable systems (chinampas and cornfield) \\
\hline & Brought to the rest of the world \\
\hline Colonial & Planting monoculture \\
\hline More sophisticated tools such as plow tillage \\
\hline Increased diversity uses \\
\hline Mexico independent & Haciendas and estates and production systems. \\
\hline Development of communications and rail export increase \\
\hline Land reform returns to the milpa \\
\hline Large irrigation works \\
\hline Use of agrochemicals, fertilizers, and improved seeds \\
\hline Sinaloa produces $50 \%$ of domestic production \\
\hline NAFTA is an important factor for the increase in exports \\
\hline Marked the separation of traditional agriculture and scientific agriculture \\
\hline technological dependence and genetic erosion of seeds \\
\hline Biotechnology
\end{tabular}

Source: own synthesis.

and growth in demand for $\mathrm{t}$ organic products in the export market.

\section{REFERENCES}

AGUILAR, J. et al. Los sistemas agrícolas de maíz y sus procesos técnicos. In: GUSTAVO E.; CATHERINE M. Sin maíz no hay país. México. Consejo Nacional para la Cultura y las Artes, p. 83-122, 2003. Available from: <http://www.culturaspopulareseindigenas. gob.mx/cp/pdf/sin_maiz_no_hay_pais.pdf $>$. Accessed: Jan. 10, 2015. ISBN 970-35-0434-5.

ALTIERI, M. La agricultura moderna: impactos ecológicos y la posibilidad de una verdadera agricultura sustentable. University of California, 2009. Available from: $<\mathrm{http}: / / \mathrm{www}$.ayuntamientomotril. es/fileadmin/areas/medioambiente/ae/IOAgriculturaModerna.pdf>. Accessed: Jan. 13, 2015

ALTIERI, M. Agroecología. Bases científicas para una agricultura sustentable. Montevideo: Editorial Nordan-Comunidad, 1999. 325p. ISBN: 9974-42-052-0.

ASTURIAS, M. A. Maíz, de alimento sagrado a negocio del hambre. Ecuador Quito: Acción Ecológica, Red por una América latina libre de transgénicos, 2004. 113p. Available from: <http:// www.estudiosecologistas.org/documentos/publicaciones/otros/maiz alimentosagrado.pdf $>$. Accessed: Jan. 12, 2015.
BAI, Y.; LINDHOUT, P. Domestication and breeding of tomatoes: what have we gained and what can we gain in the future. Annals of Botany, v.100, n.5, p.1085-1094, 2007. Available from: <https:// www.ncbi.nlm.nih.gov/pubmed/17717024>. Accessed: Jan. 15, 2015.

BARRERA, A. Nuevas realidades, nuevos paradigmas: la nueva revolución agrícola. COMUNIICA, 2011. Available from: <http:// repiica.iica.int/docs/b2144e/b2144e.pdf>. Accessed: Sept. 09, 2015.

BERRUETAC. et al. Análisis y jerarquización de factores determinantes del rendimiento de tomate para industria en Uruguay. Agrociencia Uruguay, v.16, n.2, p.39-49, 2012. Available from: <http://www.fagro. edu.uy/agrociencia/index.php/directorio/article/view/644>. Accessed: Jan. 10, 2015. ISSN: 2301-1548.

BOJACÁ, C. R. et al. Análisis de la productividad del tomate en invernadero bajo diferentes manejos mediante modelos mixtos. Revista Colombiana de Ciencias Hortícolas, v.3, n.2, p.188-198, 2009. Available from: $<\mathrm{http}$ //www.soccolhort.com/revista/pdf/magazin/vol3/ vol.3.\%20no.2/Revista_SCCH_Vol3_No2_2009.pdf $>$. Accessed: Sept. 10, 2015. ISSN: 2011-2173.

BUENO, B. I. México-Tenochtitlan: la globalización ayer y hoy. Local: Universidad Complutense de Madrid, 2006. (Anales del Museo de américa No.14). ISSN: 1133-8741, ISSN-e: 2340-5724.

CABRERA, L. Diccionario de aztequismos. México: Editorial Oasis, 1980. p 114. ISBN: 9688670383. 
CARRILLO, R. A. Tendencia histórica de la producción de jitomate en México y Sinaloa. CONACYT (U42007H), 2004. 30p. Available from: <http://www.economia.unam.mx/amhe/memoria/simposio23/ Arturo\%20CARRILLO\%20ROJAS.pdf $>$. Accessed: Sept. 25, 2015.

CERUTTI, M.; LORENZANA, G. Irrigación, expansión de la frontera agrícola y empresariado en el Yaqui (1925-1965). Revista América Latina en la Historia Económica, n.31, México ene/jun 2009. Available from: <http://www.scielo.org.mx/scielo.php?pid=S140522532009000100001\&script=sci_arttext $>$. Accessed: Sept. 10, 2015. ISSN: $1405-2253$.

CLÉMENT, J. P. Parmentier, las patatas y las ollas americanas Revista Consejo Superior de Investigaciones Científicas, v.47, n.2, 52p., 1995. Available from: <http://asclepio.revistas.csic.es/index. php/asclepio/article/viewFile/445/442>. Accessed: Oct. 14, 2015.

CRAMAUSSEL C.; CARBAJAL, L. D. El impacto demográfico de la viruela en México de la época colonial al siglo XX. Edit. Colegio Michoacano. Zamora Michoacán México, 2010. ISBN: 978-607-7764-55-7.

CRUZ, L. A. et al. Las mulas olvidadas por la historia agrícola colonial: una restitución. Revista Agricultura, Sociedad y Desarrollo, v.7, n.3, p 221-228, 2010. Available from: <http://www.colpos.mx/asyd/ revista.php? $=7 \& n=3>$. Accessed: Sept. 22, 2015. ISSN: 1870-5472.

De la ROSA, J. L. Cuantificaciones referentes a ciudad Tenochtitlan en 1519. El Colegio de Michoacán. 1986. Available from: <http://www.colmich.edu.mx/relaciones25/files/revistas/032/ JoseLuisdeRojas.pdf $>$. Accessed: Sept. 10, 2015.

EK, D. J. et al. La milpa en Yucatán, desde una perspectiva del buen vivir. Revista Veredas UAM-Xochimilco, n. spec., p.193-210, 2012. Available from: <http://148.206.107.15/biblioteca_digital/ articulos/12-648-9372izl.pdf>. Accessed: Ago. 18, 2016.

EZCURRA, E. De las chinampas a la megalópolis. El medio ambiente en la cuenca de México. México DF: Fondo de Cultura Económica, 1990. 85p. ISBN: 968-16-3478-0.

FAO. Guía metodológica. La milpa del siglo XXI. Guatemala: Organización de las Naciones Unidas para la Agricultura y la Alimentación, 2007. 66p.

GARCÍA, D. L. Agroecología y revolución verde. Madrid España: Universidad Autónoma de Madrid, 2005. Available from: $<$ http://bah ourproject.org/fondo-documental/conocimiento-libre-agroecologico/ article/agroecologia-y-revolucion-verde> . Accessed: Sept. 10, 2015.

GARCÍA, S. et al. Efectos del TLCAN sobre las exportaciones de tomate de México a los Estados Unidos. Revista Fitotecnia Mexicana, v.28, n.4, p.299-309, 2005. Available from: $<$ http://www. revistafitotecniamexicana.org/documentos/28-4/1a.pdf $>$. Accessed: Sept. 13, 2015. ISSN: 0187-7380.

GARFIAS, G. I. Evolución de la reforma agraria mexicana. In: Estudios de derecho civil. México: Editorial Instituto de

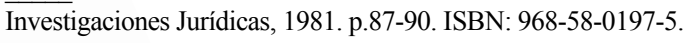

GILSANZ, J. C. Hidroponia. Uruguay: INIA, 2007. 30p. Available from: <http://www.ainfo.inia.uy/digital/bitstream/ item/520/1/11788121007155745.pdf > . Accessed: Oct. 22, 2015.

GÓMEZ, H. E. La mandrágora. Magia y mitos. Federación mexicana de jardinería u arreglos florales A. C. 30 de julio de 2011. Available from: <http://www.fmjaf.com.mx/?p=189>. Accessed: Ago. 21, 2016.
GONZÁLEZ, J. A. La agricultura nahua en el siglo XVI. Revista Ciencia Ergo Sum, v.8, n.1, p.99-107 2001. Available from: $<$ http:// www.redalyc.org/pdf/104/10402014.pdf>. Accessed: Sept. 10, 2015. ISSN: $1405-0269$

GONZÁLEZ, J. A. Ambiente y cultura en la agricultura tradicional de México: casos y perspectivas. Ciencia Ergo Sum, v.11, n.2, p.153163, 2003. Available from: <http://www.revistas.unam.mx/index.php/ antropologia/article/viewFile/16738/pdf_153>. Accessed: Jan. 10, 2015. ISSN 1405-0269.

GONZÁLEZ, C. E.; TORRES, V. C. La sustentabilidad agrícola de las chinampas en el valle de México: caso Xochimilco. Revista Mexicana de Agronegocios, v. XVIII, n.34, p.699-709, 2014. Available from: $<$ http://www.redalyc.org/pdf/141/14131514005.pdf>. Accessed: Jan. 10, 2015. ISSN: 1405-9282.

HAEFF, V. J. Manuales para educación agropecuaria, área: producción vegetal. México D. F.: Editorial Trillas, 1983. 77p.

HERNÁNDEZ, R. I. Estudio de la trayectoria y prospectiva de la innovación tecnológica en la cadena agroalimentaria del tomate. San Luis Potosí: Colegio de Posgraduados, 2003. 20p.

JOHANSSON, P. La muerte en la cosmovisión náhuatl prehispánica. Consideraciones heurísticas y epistemológicas. Revista Estudios de cultura náhuatl, v.43, p.47-93, 2012. Available from: $<$ http://www. revistas.unam.mx/index.php/ecn/article/view/30513>. Accessed: Sept. 10, 2015.

JUÁREZ, L. P. et al. Horticultura protegida en Nayarit, México: situación actual y perspectivas. Revista Bio Ciencias, v.1, n.4, p.16-24, 2012.

LONG, J. Tomate y jitomate en el siglo XVI. Instituto de Investigaciones Históricas de la UNAM 2013. Available from: <http://www.historicas. unam.mx/publicaciones/revistas/nahuatl/pdf/ecn25/463.pdf>. Accessed: Sept. 22, 2015.

LÓPEZ, E. J. Cien años de despojo y explotación de los peones indígenas en tierras sinaloenses. In: El México bárbaro del siglo XXI. México D. F.: Universidad Autónoma Metropolitana, 2013. p.279-304.

LÓPEZ, L. L. Teotihuacan y Tenochtitlan: la vinculación histórica como elemento de legitimación. Lateinamerika. Semesterbericht des Lateinamerika-Instituts der Universität Rostock, v.25, n.1, p.22-33, 1990. Available from: <http://www.mesoweb.com/about/ articles/Teotihuacan-y-Tenochtitlan.pdf $>$. Accessed: Jan. 10, 2015.

MEYER Y. Haciendas y ranchos, peones y campesinos en el porfiriato. Algunas falacias estadísticas. Revista del Colegio de Michoacán, v.35, n.3. p.477-509, 1986. Available from: <https://www.jstor.org/ stable/25135950?seq=1\#page_scan_tab_contents $>$. Accessed: Oct. $20,2016$.

MONDRAGÓN, S. L. Producción de jitomate en invernadero. Metepec México: ICAMEX, SEDAGRO, 2007. 11p.

OLIMÓN, N. M. Entretelones de una oposición. La iglesia católica y las leyes de reforma. Coloquio internacional $\mathrm{La}$ reforma en la historia y en la memoria. El Colegio de México, Ciudad de México, 14 de octubre de 2009. Available from: <http://www.olimon.org/manuel/ ponencias/entretelones.htm\#_ftn11>. Accessed: Ago. 21, 2016.

ORTEGA, M. L. et al. Efecto de diferentes sustratos en crecimiento $\mathrm{y}$ rendimiento de tomate (Lycopersicum esculentum mill) bajo condiciones de invernadero. Ra Ximhai, v.6, n.3, p.339-346, 2010. 
Available from: $<$ http://www.redalyc.org/pdf/461/46116015005.pdf $>$. Accessed: Oct 28, 2015. ISSN: 1665-0441.

PACHECO, A. Fundamentos técnicos para el diseño y construcción de invernaderos. Revista 2000Agro, 15 agosto 2008. Available from: $<\mathrm{http}: / /$ www.2000agro.com.mx/agroindustria/fundamentos-tecnicos-para-eldiseno-y-construccion-de-invernaderos/>. Accessed: Oct. 23, 2015.

PERALTA, I. E. et al. Las nuevas especies de tomates silvestres (Solannum sección Lycopersicon: Solanaceae) desde el norte de Perú. Botánica sistemática, v.30, n.2, p.424-434, 2005. ISSN: 0363-6445.

PERALTA, I. E.; SPOONER, D. M. History, origin and early cultivation of tomato (Solanaceae). In: RAZDAN, M.K.; MATTOO, A. K. (EDS.). Genetic improvement of solanaceous crops. Vol. 2. Enfield, Nueva Hampshire: Science Publishers, 2007. V.2, p.1-27.

PORCUNA, J. L. et al. El tomate, planteamientos sanitarios para un cultivo muy vulnerable para el residuo cero. Revista Vida Rural, n.342, p. 52-57, 2012. Available from: <http://www.eumedia.es/ portales/files/documentos/tomate_VR342.pdf>. Accessed: Oct. 20, 2015. ISSN: 1133-8938.

REMMERS, G. G. Agricultura tradicional y agricultura ecológica: vecinos distantes. Agricultura y Sociedad, n.66, p201-220, 1993. Available from: <https://dialnet.unirioja.es/servlet/ articulo? codigo $=82907>$. Accessed: Oct. 12, 2015. ISSN: 0211-8394.

RODRÍGUEZ, E. et al. Lo que usted debe saber sobre: Los animales transgénicos (y organismos manipulados genéticamente. España: Edición Caja España. 2003. 70p. ISBN: 84-95917-10-6.

ROMÁN, A. A. La reforma agraria cardenista en México, el caso de Sinaloa 1934- 1940. In: CONGRESO INTERNACIONAL DE HISTORIA AGRARIA, 14., 2013, Badajoz, España. Available from: $<$ http://seha.info/congresos/articulos/P.II.\%20Rom\%C3\%A1n. pdf $>$. Accessed: Oct. 20, 2015.

RUBIO, F. B. México-Tenochtitlan: Urbanismo de la capital azteca. Universidad Complutense de Madrid. Anales del Museo de América, n.15, p.21-37, 2007, ISSN: 1133-8741, ISSN-e: 2340-5724.

SAGARPA. Monografías del cultivo jitomate. México: Subsecretaría de Fomento a los Agronegocios, 2010. (Boletín Técnico, agosto).

SAGARPA. Produce México 39.5 toneladas de jitomates por cada hectárea. México D. F. 08 de diciembre de 2013. Available from: $<$ http://www.siap.gob.mx/produce-39-toneladas-jitomate $>$. Accessed: Ago. 18, 2016.

SAGARPA. Se consolida México como primer exportador mundial de tomate. San Luis Potosí, SLP, 15 de julio de 2015. Comunicado de Prensa NUM. 466/15. Available from: <http://www.sagarpa.gob. $\mathrm{mx} /$ saladeprensa/2012/2015/julio/Documents/2015B466.PDF>. Accessed: Ago. 18, 2016.

SÁNCHEZ, C. G. Programa estratégico de necesidades de investigación y transferencia de tecnología de la cadena productiva del estado de Puebla. Puebla: Corporación Chapingo, 2003. 80p.
SEGRELLES, J. A. El problema de los cultivos transgénicos en América Latina: una "nueva" Revolución Verde. Revista Entorno Geográfico, n.3, p.93-120, 2005. Available from: <http:// entornogeografico.com/index.php/EntornoGeografico/article/ view/23/24>. Accessed: Oct. 25, 2015.

SCHETTINO, M. Estimación de la actividad económica en México durante la Revolución. Documento de Trabajo EGAP2007-12 Tecnológico de Monterrey, México, 2007. Available from: $<$ http://alejandria.ccm.itesm.mx/egap/documentos/EGAP-200712.pdf>. Accessed: Oct. 20, 2015.

SIMS, W. L. History of tomato production for industry around the world. Act Horticulturae, v.100, p. 25-26, 1980. Available from: $<$ http://www.actahort.org/books/100/100 1.htm>. Accessed: Oct. 22, 2015, doi: 10.17660 .

SNYDER, R. Guía del cultivo del tomate en invernadero Mississippi State University, 2006. Available from: $<$ http://msucares. com/espanol/pubs/p2419.pdf>. Accessed: Sept. 09, 2015.

SOTO, M. C. La agricultura comercial de los distritos de riego en México y su impacto en el desarrollo agrícola. Investigaciones Geográficas, n.50, p. 173-195, 2003. Available from: <http:// www.scielo.org. $\mathrm{mx} / \mathrm{scielo} . \mathrm{php}$ ? script $=\mathrm{sci}$ arttext\&pid $=$ S0188-46112003000100016 $>$. Accessed: Oct. 25, 2015. ISSN: 0188-4611.

TOLEDO, M. V. Agroecología, sustentabilidad y reforma agraria: la superioridad de la pequeña producción familiar. Revista Agroecología e Desenvolvimiento Rural Sustentable, v.3, n.2, p.10 2002. Available from: <https://www.ucm.es/data/cont/media/ www/pag-79266/V.\%20Toledo $\% 20 \mathrm{La} \% 20$ superioridad $\% 20$ de $\% 201 \mathrm{a} \% 20$ peque $\%$ C3\%B 1 a $\% 20$ producci $\%$ C $3 \%$ B 3 n $\% 20$ familiar.pdf $>$. Accessed: Sept. 30, 2015.

VELA, E. La calabaza, el tomate y el frijol. Revista Arqueología Mexicana. Edición 137, 2013. Available from: $<$ http://www.arqueomex.com/S11N3ANTERIORES.html $>$. Accessed: Sept. 10, 2015.

VERGANI, G. R. Lycupersicum esculentum: una breve historia del tomate. Revista Horticultura, v. 158, p. 9., 2002. Available from: <http://www.horticom.com/pd/imagenes/50/956/50956. pdf>. Accessed: Ago, 21, 2016.

ZAVALA, V. S. Yucatán en el tiempo. Mérida, Yucatán: Enciclopedia Yucatán en el tiempo, 1998. V.4, 274p.

ZULETA, M. C. La Secretaría de Fomento y el fomento agrícola en México, 1876-1910: la invención de una agricultura próspera que no fue. Mundo Agrario. Revista de Estudios Rurales, v.1, n.1, p. 41 segundo semestre de 2000. E-ISSN: $1515-5994$.

ZÚÑIGA, A.; CASTILlO, L. La Revolución de 1910 y el mito del ejido mexicano. Alegratos, n. 75, p. 497-522, 2010. Available from: <http://www.azc.uam.mx/publicaciones/alegatos/ pdfs/68/75-07.pdf>. Accessed: Jan. 10, 2015. ISSN: 0187-5973. 